\title{
A Production Planning Model For Reconfigurable Lines
}

Kingsley Gnanendran, University of Scranton, USA

Manohar Madan, University of Wisconsin-Whitewater, USA

\begin{abstract}
A key indicator of the efficiency of a production line is cyclic idle time. Manufacturers use heuristic line balancing techniques to determine the allocation of elemental tasks to workers so as to minimize labor costs. The productive, i.e. non-idle, portion of each cycle then reflects the efficiency of the line. Line balancing techniques determine the allocation of tasks based on a prespecified throughput. When demand changes however, the line may have to be reconfigured to reflect the new desired flow rate, resulting possibly in a lower efficiency and a higher per-unit labor cost. This raises an interesting question: should one use a flow rate that corresponds to the higher efficiency, handling any mismatch with demand through the use of inventory or backordering, or should the aim be to match flow rate precisely with demand rate even though the resulting efficiency might be lower? This paper proposes an answer to this question by embedding line balance and efficiency into the framework of a well-known production planning model. A heuristic method for solving the extended model is developed, and its application demonstrated using numerical examples.
\end{abstract}

Keywords: Production Planning; Capacitated Lot-Sizing; Assembly Line Balancing; Reconfigurable Lines

\section{INTRODUCTION}

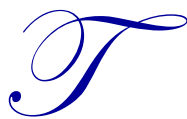

ypical production planning approaches weigh production, inventory, and setup costs in determining production lot sizes, with the implicit assumption that the production process is operating at $100 \%$ efficiency. This is rarely the case since efficiency depends on how well the production line was designed (balanced) in the first place. Manufacturers commonly use line balancing procedures (e.g. Scholl and Becker (2006)) to determine the allocation of elemental tasks to workers so as to minimize per-unit labor costs. The productive portion of each cycle reflects the efficiency of the line. Thus, the line balancing process determines not only the line's capacity (units per shift) but also the per-unit production cost since the amount of input labor (minutes/unit) crucially depends on the efficiency attained by the line balance. The trade-off inherent in this situation is: should the manufacturer match production quantity exactly to demand and save on inventory holding and backordering costs, or produce at a different, but more efficient, rate and save on labor costs?

Our research explores an integrated approach for addressing this combined line efficiency/production planning problem. This would be applicable to manufacturing environments where assembly lines can be reconfigured relatively easily and at short notice, perhaps even from one shift to the next. Examples of such environments include lines equipped with flexible automation, or the kinds of manual assembly lines that are routinely used in the production of high-tech items, for example cellphones, digital cameras, and tablet computers. An approach using reconfigured lines and multi-skilled workers to absorb demand variability is presented in Garg, Vrat, and Kanda (2002). Our work here, however, is more directly motivated by the discussion of the trade-off between efficiency and capacity given in Meredith and Shafer (2010).

Once an efficiency level is chosen and the line reconfigured to conform to that balance, the labor (payroll) cost for that shift becomes a fixed cost, analogous to the setup cost in the conventional lot-sizing problem. In light of this observation, the combined line efficiency/production planning problem may also be viewed from the perspective of lot-sizing theory. While there is a rich body of research in the area of lot-sizing, the most commonly 
considered trade-off is between setup cost and inventory cost (see Cheng et. al. (2010), Jans and Degreave (2007), or Brahimi et al. (2006) for extensive reviews of this area). There are many significant variations of the lot-sizing problem, and researchers such as Eisenhut (1975), Lambrecht and Vanderveken (1979), Dixon and Silver (1981), Dogramaci et al. (1981), Maes and van Wassenhove (1988), Gilbert and Madan (1991), Madan and Gilbert (1992), Diaby et al. (1992), Millar and Yang (1993), and Millar and Yang (1994) have proposed mathematical programming formulations and heuristics specifically for capacitated lot-sizing, the problem that is most closely related to the situation discussed here. In our research however, we have incorporated the additional notion of line efficiency, recognizing that capacity may be different in different periods depending on the specific line balance chosen for that period. To our knowledge, no past research has explicitly included line balance in the lot-sizing context.

\section{ESTIMATING LABOR COSTS IN ASSEMBLY LINES}

The flow rate of a production line is the reciprocal of the cycle time. Thus:

Flow Rate $=1 /$ Cycle Time

The cycle time required to achieve a desired flow rate is found by inverting this relation:

Cycle Time $=1 /$ Flow Rate

The minimum cycle time (or maximum flow rate) is limited by the slowest, or bottleneck, process on the line. The theoretical minimum number of workers needed to achieve a given flow rate is:

where:

Minimum Number of Workers $=$ Work Content $/$ Cycle Time

Work Content $=$ Sum of Process Times

In practice this theoretical lower bound is not always attainable since the sum of process times allocated to a given worker may not add up to the cycle time precisely. This causes idle time on the line leading to inefficiency and higher labor costs. A measure of how well the processes were allocated may be computed by:

Line Efficiency $=$ Work Content $/$ Input Labor

where:

Input Labor $=$ Actual Number of Workers $\times$ Cycle Time

An alternate definition of line efficiency is:

Line Efficiency = Minimum Number of Workers / Actual Number of Workers

Finally, the per-unit labor cost is:

Per-Unit Labor Cost $=$ Input Labor $\times$ Wage Rate

To illustrate, consider a production line with three serial processes $(A, B$, and $C)$ with process times of 12 , 10 , and 20 minutes respectively and a wage rate of $\$ 45$ per hour (Figure 1). 
Figure 1. Line Balancing Example

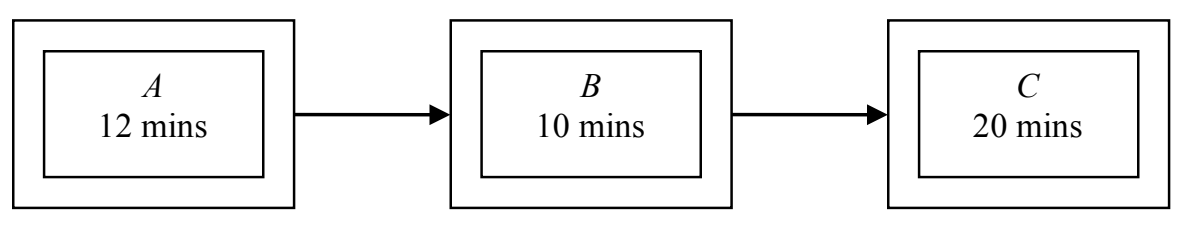

The bottleneck process here is $C$ which results in a minimum cycle time of 20 minutes or, equivalently, a maximum flow rate of 3 units per hour. The work content is 42 minutes, the (theoretical) minimum number of workers is $42 / 20=2.1$, input labor is $3 \times 20=60$ minutes, and line efficiency is $42 / 60=70 \%$ (equivalently $2.1 / 3$ ). The per-unit labor cost is 60 minutes $\times \$ 45 /$ hour $=\$ 45.00 /$ unit. Thus, we conclude that a flow rate of 3 units/hour can be sustained at a labor cost of $\$ 45.00 /$ unit.

Now suppose that it is desired to increase the flow rate to 6 units/hour. The required cycle time of 10 minutes can be attained by "paralleling", i.e., using multiple workers for processes whose times exceeds the required cycle time. In this case, we would need 2 workers each at $A$ and $C$ yielding effective process times of 6 minutes and 10 minutes respectively. It can be seen that the input labor is 50 minutes, line efficiency is $84 \%$, and labor cost is $\$ 37.50 /$ unit.

A more interesting situation arises when we attempt to balance the line at a flow rate of 4 units /hour. The resulting cycle time of 15 minutes means an extra worker would be needed at process $C$, resulting in input labor of 4 $\times 15=60$ minutes and line efficiency of $70 \%$. However, a better solution can be found by combining processes $B$ and $C$ into a single entity with process time of 30 minutes (Figure 2).

Figure 2. Combining Processes Prior to Paralleling

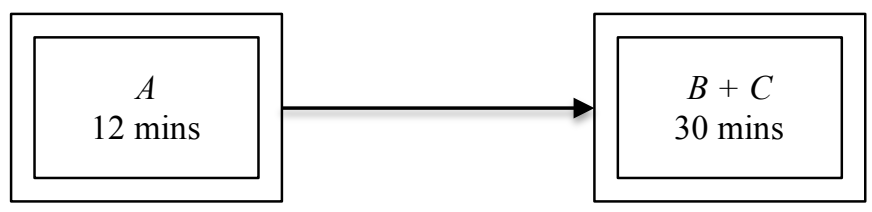

Now only three workers are needed (one at process $A$, and two at the combined process $B+C$ ) leading to input labor of $3 \times 15=45$ minutes, line efficiency of $93.33 \%$, and per-unit labor cost of $\$ 33.75 /$ unit. These results (Table 1) demonstrate that the per-unit labor cost is a function of the cycle time, and hence, the chosen flow rate.

Table 1. Line Balancing Example: Summary

\begin{tabular}{cccc}
\hline Flow Rate (units/hour) & Cycle Time (minutes) & Line Efficiency & Per-Unit Labor Cost \\
\hline 3 & 20 & $70.00 \%$ & $\$ 45.00$ \\
4 & 15 & $93.33 \%$ & $\$ 33.75$ \\
6 & 10 & $84.00 \%$ & $\$ 37.50$ \\
\hline
\end{tabular}

\section{EXAMPLE}

In this section, we use an example from Meredith and Shafer (2010, p. 327) to further illustrate this concept. They consider four resources in series $(A, B, C, D)$ with process times of 4,3 , 10, and 2 minutes respectively (Figure 3).

Figure 3. Example from Meredith and Shafer (2010)

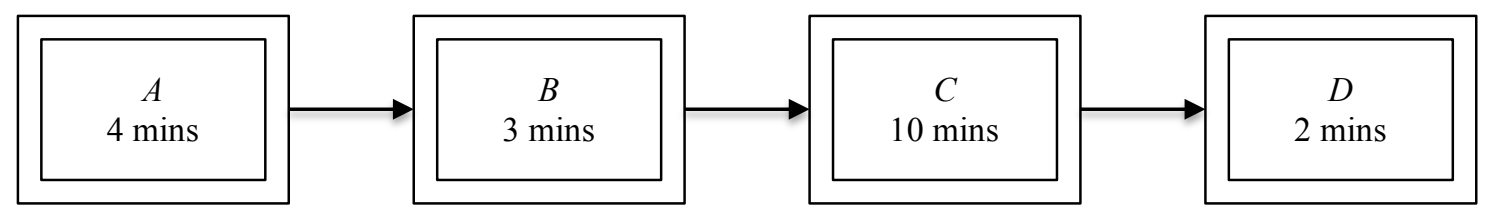


In the original, each resource was assumed to be a machine, but the concepts apply equally well if the resources are workers, and the example has been adapted to reflect this. In the base case (one worker per process), the cycle time is 10 minutes leading to an hourly output is 6 units/hour and an efficiency of $47.5 \%$. The bottleneck at this point is Process $C$, and if an extra worker is added to this particular process, the bottleneck process time is halved to 5 minutes, resulting in an hourly output of 12 units per hour and efficiency of $76 \%$. To further improve output, yet another worker can be added at the current bottleneck (still Process $C$ ), leading to a cycle time of 4 minutes (note that the bottleneck now shifts to Process $A$ ). The resulting hourly output is 15 units per hour at an efficiency of $79.2 \%$. One can continue to increase flow rate in this fashion by adding, at each stage, one additional worker to the current bottleneck process (Table 2). Observe that, unlike flow rate, efficiency does not increase monotonically with the number of workers.

Table 2. Flow Rate and Efficiency $v s$. Number of Workers

\begin{tabular}{|c|c|c|c|c|c|c|c|c|}
\hline \multirow{2}{*}{$\begin{array}{l}\text { Number of } \\
\text { Workers }\end{array}$} & \multirow{2}{*}{$\begin{array}{c}\text { Next } \\
\text { Worker }\end{array}$} & \multicolumn{4}{|c|}{ Process Times (minutes) } & \multirow{2}{*}{$\begin{array}{c}\text { Cycle Time } \\
\text { (minutes) }\end{array}$} & \multirow{2}{*}{$\begin{array}{c}\text { Flow Rate } \\
\text { (units/hour) }\end{array}$} & \multirow{2}{*}{ Efficiency } \\
\hline & & $A$ & $B$ & $C$ & D & & & \\
\hline 4 & & 4 & 3 & 10 & 2 & 10 & 6 & $47.5 \%$ \\
\hline 5 & $C$ & 4 & 3 & 5 & 2 & 5 & 12 & $76.0 \%$ \\
\hline 6 & $C$ & 4 & 3 & 3.33 & 2 & 4 & 15 & $79.2 \%$ \\
\hline 7 & $A$ & 2 & 3 & 3.33 & 2 & 3.33 & 18 & $81.4 \%$ \\
\hline 8 & $C$ & 2 & 3 & 2.50 & 2 & 3 & 20 & $79.2 \%$ \\
\hline 9 & $B$ & 2 & 1.5 & 2.50 & 2 & 2.50 & 24 & $84.4 \%$ \\
\hline 10 & $C$ & 2 & 1.5 & 2 & 2 & 2 & 30 & $95.0 \%$ \\
\hline 11 & $A$ & 1.33 & 1.5 & 2 & 2 & 2 & 30 & $86.4 \%$ \\
\hline 12 & $C$ & 1.33 & 1.5 & 1.67 & 2 & 2 & 30 & $79.2 \%$ \\
\hline 13 & $D$ & 1.33 & 1.5 & 1.67 & 1 & 1.67 & 36 & $87.7 \%$ \\
\hline 14 & $C$ & 1.33 & 1.5 & 1.43 & 1 & 1.50 & 40 & $90.5 \%$ \\
\hline
\end{tabular}

To illustrate how this information can be incorporated into production planning, we pick the flow rates corresponding to the three highest efficiencies in Table 2 as production options for a 2-period problem with demands of 200 and 350. Applying an assumed labor cost of $\$ 45$ per hour and an 8-hour production day, the per-unit labor costs and 8-hour capacities are summarized in Table 3.

Table 3. Costs and Capacities for Chosen Flow Rates

\begin{tabular}{cccccc}
\hline $\begin{array}{c}\text { Number of } \\
\text { Workers }\end{array}$ & $\begin{array}{c}\text { Cycle Time } \\
\text { (minutes) }\end{array}$ & $\begin{array}{c}\text { Input Labor } \\
\text { (minutes/unit) }\end{array}$ & $\begin{array}{c}\text { Per-Unit Labor } \\
\text { Cost }\end{array}$ & $\begin{array}{c}\text { Flow Rate } \\
\text { (units/hour) }\end{array}$ & 8-hour Capacity \\
\hline 10 & 2.00 & 20.00 & $\$ 15.00$ & 30 & 240 \\
13 & 1.67 & 21.67 & $\$ 16.25$ & 36 & 288 \\
14 & 1.50 & 21.00 & $\$ 15.75$ & 40 & 320 \\
\hline
\end{tabular}

Assuming per-unit inventory holding and backorder costs of $\$ 2$ and $\$ 4 /$ unit/period respectively, the available production options and corresponding costs are displayed in Table 4 using the well-known transportation tableau for production planning (see e.g. Krajewski, Ritzman, and Malhotra (2013), p. 600).

Table 4. Production Planning Tableau

\begin{tabular}{|c|c|c|c|c|}
\hline Period & Production Option & Period 1 & Period 2 & Capacity \\
\hline \multirow{3}{*}{ Period 1} & 10 workers & $\$ 15.00$ & $\$ 15.00+2.00$ & 240 \\
\hline & 13 workers & $\$ 16.25$ & $\$ 16.25+2.00$ & 288 \\
\hline & 14 workers & $\$ 15.75$ & $\$ 15.75+2.00$ & 320 \\
\hline \multirow{3}{*}{ Period 2} & 10 workers & $\$ 15.00+4.00$ & $\$ 15.00$ & 240 \\
\hline & 13 workers & $\$ 16.25+4.00$ & $\$ 16.25$ & 288 \\
\hline & 14 workers & $\$ 15.75+4.00$ & $\$ 15.75$ & 320 \\
\hline Demand & & 200 & 350 & \\
\hline
\end{tabular}

Here however, unlike the traditional production planning problem, at most only one production option can be chosen in each period. This necessitates the introduction of binary variables and, in the next section, we develop a formal optimization model for this problem. 


\section{OPTIMIZATION MODEL}

Given a set of demands for a single product over a finite planning horizon, traditional production planning models attempt to answer the question: how many units are to be produced in each period? Specifically, we are interested in both the magnitude and timing of production decisions. If the objective is to minimize only the sum of production costs (in regular-time (RT) and overtime (OT)) and inventory costs (holding, backordering) - i.e. there are no production setup costs - this problem can be modeled as a transportation linear program [Bowman (1963)], with the tableau corresponding to the one shown in Table 5. Here, per-unit costs for regular-time production, overtime production, inventory holding, and inventory backordering are denoted as $R, O, H$, and $B$ respectively, while $R C$ and $O C$ denote the available regular-time and overtime capacities, and $D_{i}$ the demand, in Period $i$.

Table 5. Bowman's Tableau for Traditional Production Planning

\begin{tabular}{|c|c|c|c|c|c|c|}
\hline Period & Capacity Type & Period 1 & Period 2 & $\ldots$ & Period $N$ & Capacity \\
\hline \multirow{2}{*}{1} & $\mathrm{RT}$ & $R$ & $R+H$ & $\ldots$ & $R+(N-1) H$ & $R C$ \\
\hline & OT & $O$ & $O+H$ & $\ldots$ & $O+(N-1) H$ & $O C$ \\
\hline \multirow{2}{*}{2} & RT & $R+B$ & $R$ & $\ldots$ & $R+(N-2) H$ & $R C$ \\
\hline & OT & $O+B$ & $O$ & $\ldots$ & $O+(N-2) H$ & $O C$ \\
\hline$\ldots$ & $\ldots$ & $\ldots$ & $\ldots$ & $\ldots$ & $\ldots$ & $\ldots$ \\
\hline \multirow{2}{*}{$N$} & RT & $R+(N-1) B$ & $R+(N-2) B$ & $\ldots$ & $R$ & $R C$ \\
\hline & OT & $O+(N-1) B$ & $O+(N-2) B$ & $\ldots$ & $O$ & $O C$ \\
\hline Demand & & $D_{1}$ & $D_{2}$ & $\ldots$ & $D_{N}$ & \\
\hline
\end{tabular}

Bowman's approach however assumes that production cost is independent of production capacity. As we have demonstrated previously, this assumption is not always valid since the resulting per-unit production cost depends on how well the line was balanced in the first place, i.e. different target output rates may give rise to different line efficiencies and, hence, different per-unit production costs. Moreover, at most only one efficiency level may be chosen in each period. Also, once an efficiency level was picked and the line reconfigured to conform to that balance, the labor cost (payroll) for that shift becomes a fixed commitment and analogous to a setup cost. Below, we extend Bowman's model to take these aspects into consideration. This is similar to the approach taken in Madan and Gilbert (1992) of addressing a class of lot-sizing problems as a variant of the fixed-charge transportation problem. Our extended production planning problem can be formulated as the following $0-1$ mixed integer program.

Parameters

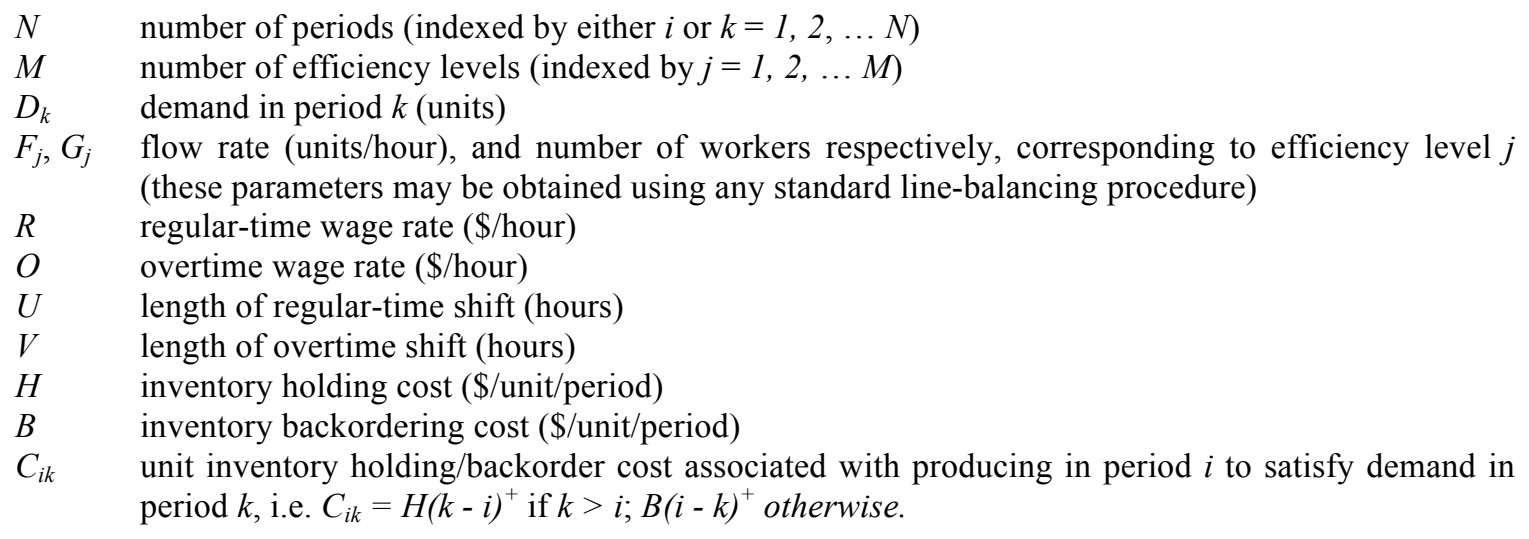




\section{Variables}

$X_{i j k} \quad$ quantity produced in regular-time in period $i$ using efficiency level $j$ to satisfy demand in period $k$

$Y_{i j k} \quad$ quantity produced in overtime in period $i$ using efficiency level $j$ to satisfy demand in period $k$

$Z_{i j} \quad$ a binary variable indicating whether efficiency level $j$ is chosen in regular-time in period $i$

$W_{i j} \quad$ a binary variable indicating whether efficiency level $j$ is chosen in overtime in period $i$

Model

Minimize $R U \sum_{i j} G_{j} Z_{i j}+O V \sum_{i j} G_{j} W_{i j}+\sum_{i j k} C_{i k}\left(X_{i j k}+Y_{i j k}\right)$

Subject to:

$$
\begin{array}{ll}
\sum_{k} X_{i j k} \leq U F_{j} Z_{i j} & i=1,2, \ldots N ; j=1,2, \ldots M \\
\sum_{k} Y_{i j k} \leq V F_{j} W_{i j} & i=1,2, \ldots N ; j=1,2, \ldots M \\
\sum_{i, j}\left(X_{i j k}+Y_{i j k}\right)=D_{k} & k=1,2, \ldots N \\
\sum_{j} Z_{i j} \leq 1 & i=1,2, \ldots N \\
W_{i j} \leq Z_{i j} & i=1,2, \ldots N ; j=1,2, \ldots M \\
X_{i j k}, Y_{i j k} \geq 0 & i, k=1,2, \ldots N ; j=1,2, \ldots M \\
Z_{i j}, W_{i j}=0 \text { or } 1 & i=1,2, \ldots N ; j=1,2, \ldots M
\end{array}
$$

The objective function (1) minimizes the sum of production (regular-time and overtime labor) and inventory (holding and backordering) costs over a planning horizon of $N$ periods. Constraints (2) and (2') ensure that capacity restrictions are not exceeded in each regular-time and overtime period. These capacity limits are based on the flow rate corresponding to each efficiency level. Constraint (3) ensures that demand is satisfied. Constraint (4) stipulates that at most one efficiency level may be chosen in any regular-time period. Once chosen however, that efficiency level may optionally be carried over to overtime in that period (Constraint ( $\left.4^{\prime}\right)$ ). Constraints (5) and ( $\left.5^{\prime}\right)$ reflect the non-negative and binary nature of the respective decision variables. The variable costs of inventory holding and backordering, i.e. $C_{i k}$, are depicted in the revised tableau shown in Table 6. Because this formulation also has fixed (setup) cost aspects, it cannot be solved using standard linear programming. The model (1)-(5') can be viewed as a type of transportation problem. However, it should be noted that unlike the conventional transportation problem, this model has 0-1 integer variables associated with the flows in groups of cells. In the next section, present a heuristic for the case where backordering is not allowed. 
Table 6. Revised Bowman's Tableau for Production Planning with Multiple Efficiency Levels ( $C_{i k}$ only)

\begin{tabular}{|c|c|c|c|c|c|c|c|}
\hline Period & Efficiency Level & Capacity Type & Period 1 & Period 2 & $\ldots$ & Period $N$ & Capacity \\
\hline \multirow{4}{*}{1} & Level 1 & $\begin{array}{l}\text { RT } \\
\text { OT }\end{array}$ & $\begin{array}{l}0 \\
0\end{array}$ & $\begin{array}{l}H \\
H\end{array}$ & $\begin{array}{l}\ldots \\
\ldots\end{array}$ & $\begin{array}{l}(N-1) H \\
(N-1) H\end{array}$ & $\begin{array}{l}U F_{1} \\
V F_{I}\end{array}$ \\
\hline & Level 2 & $\begin{array}{l}\text { RT } \\
\text { OT }\end{array}$ & $\begin{array}{l}0 \\
0\end{array}$ & $\begin{array}{l}H \\
H\end{array}$ & $\begin{array}{l}\ldots \\
\ldots\end{array}$ & $\begin{array}{l}(N-1) H \\
(N-1) H\end{array}$ & $\begin{array}{l}U F_{2} \\
V F_{2}\end{array}$ \\
\hline & $\ldots$ & $\ldots$ & $\ldots$ & $\ldots$ & $\ldots$ & $\ldots$ & $\ldots$ \\
\hline & Level $M$ & $\begin{array}{l}\text { RT } \\
\text { OT }\end{array}$ & $\begin{array}{l}0 \\
0\end{array}$ & $\begin{array}{l}H \\
H\end{array}$ & $\begin{array}{l}\ldots \\
\ldots\end{array}$ & $\begin{array}{l}(N-1) H \\
(N-1) H\end{array}$ & $\begin{array}{l}U F_{M} \\
V F_{M}\end{array}$ \\
\hline \multirow{4}{*}{2} & Level 1 & $\begin{array}{l}\text { RT } \\
\text { OT }\end{array}$ & $\begin{array}{l}B \\
B\end{array}$ & $\begin{array}{l}0 \\
0\end{array}$ & $\begin{array}{l}\ldots \\
\ldots\end{array}$ & $\begin{array}{l}(N-2) H \\
(N-2) H\end{array}$ & $\begin{array}{l}U F_{1} \\
V F_{I}\end{array}$ \\
\hline & Level 2 & $\begin{array}{l}\text { RT } \\
\text { OT }\end{array}$ & $\begin{array}{l}B \\
B\end{array}$ & $\begin{array}{l}0 \\
0 \\
\end{array}$ & $\begin{array}{l}\ldots \\
\ldots\end{array}$ & $\begin{array}{l}(N-2) H \\
(N-2) H\end{array}$ & $\begin{array}{l}U F_{2} \\
V F_{2} \\
\end{array}$ \\
\hline & $\ldots$ & $\ldots$ & $\ldots$ & $\ldots$ & $\ldots$ & $\ldots$ & $\ldots$ \\
\hline & Level $M$ & $\begin{array}{l}\text { RT } \\
\text { OT }\end{array}$ & $\begin{array}{l}B \\
B\end{array}$ & $\begin{array}{l}0 \\
0\end{array}$ & $\begin{array}{l}\ldots \\
\ldots\end{array}$ & $\begin{array}{l}(N-2) H \\
(N-2) H\end{array}$ & $\begin{array}{l}U F_{M} \\
V F_{M}\end{array}$ \\
\hline$\ldots$ & $\ldots$ & $\ldots$ & $\ldots$ & $\ldots$ & $\ldots$ & $\ldots$ & $\ldots$ \\
\hline \multirow{4}{*}{$N$} & Level 1 & $\begin{array}{l}\text { RT } \\
\text { OT }\end{array}$ & $\begin{array}{l}(N-1) B \\
(N-1) B\end{array}$ & $\begin{array}{l}(N-2) B \\
(N-2) B\end{array}$ & $\begin{array}{l}\ldots \\
\ldots\end{array}$ & $\begin{array}{l}0 \\
0\end{array}$ & $\begin{array}{l}U F_{1} \\
V F_{1}\end{array}$ \\
\hline & Level 2 & $\begin{array}{l}\text { RT } \\
\text { OT }\end{array}$ & $\begin{array}{l}(N-1) B \\
(N-1) B\end{array}$ & $\begin{array}{l}(N-2) B \\
(N-2) B\end{array}$ & $\ldots$ & $\begin{array}{l}0 \\
0 \\
\end{array}$ & $\begin{array}{l}U F_{2} \\
V F_{2}\end{array}$ \\
\hline & $\ldots$ & $\ldots$ & $\ldots$ & $\ldots$ & $\ldots$ & $\ldots$ & $\ldots$ \\
\hline & Level $M$ & $\begin{array}{l}\text { RT } \\
\text { OT }\end{array}$ & $\begin{array}{l}(N-1) B \\
(N-1) B\end{array}$ & $\begin{array}{l}(N-2) B \\
(N-2) B\end{array}$ & $\begin{array}{l}\ldots \\
\ldots\end{array}$ & $\begin{array}{l}0 \\
0\end{array}$ & $\begin{array}{l}U F_{M} \\
V F_{M}\end{array}$ \\
\hline Demand & & & $D_{I}$ & $D_{2}$ & $\ldots$ & $D_{N}$ & \\
\hline
\end{tabular}

\section{HEURISTIC}

The heuristic consists of two phases: (i) a construction phase to identify a "good" feasible solution; and (ii) an improvement phase to derive an even "better" solution, i.e. one that is closer to the optimal solution.

\section{Construction Phase}

Step 1. Initialize the deficit $D E F_{i}$ in each period:

$$
D E F_{i}=D_{i} \quad(i=1,2, \ldots N)
$$

Step 2. For period $i=N$ down to 1 do:

2.1 Identify the cheapest efficiency level $p$ in period $i$ that will satisfy current period's demand plus all future deficits, i.e. $(U+V) F_{p} \geq D_{i}+\sum_{k=i+1}^{k=N} D E F_{k}$. (If none of the current period's efficiency levels has sufficient capacity to satisfy this quantity, choose $p$ to be the level with the largest combined $(R T+O T)$ capacity regardless of cost.)

2.2 Initialize the surplus capacity in period $i$ and efficiency level $p$ for the regular-time shift (RT capacity type):

$$
S U R_{i p R}=U F_{p}
$$

If overtime was needed to be invoked in period $i$ with efficiency level $p$ to satisfy quantity in Step 2.1 above, then initialize the surplus capacity in period $i$ and efficiency level $p$ for the overtime shift (OT capacity type) also:

$$
S U R_{i p o}=V F_{p}
$$


2.3 Assign $X_{i p k}$ and $Y_{i p k}$, in that order, to appropriate values by comparing the relative magnitudes of:

(i) $D_{i}$; (ii) total of future deficits $\sum_{k=i+1}^{k=N} D E F_{k}$; (iii) $S U R_{i p R}$; and (iv) $S U R_{i p o}$.

2.4 Update all deficits in periods $i$ through $N$ :

$$
D E F_{k}=D_{k}-\sum_{i=1}^{N} \sum_{j=1}^{M} X_{i j k}-\sum_{i=1}^{N} \sum_{j=1}^{M} Y_{i j k} \quad(k=i, i+1, \ldots N)
$$

2.5 Update surplus capacity in period $i$ and efficiency level $p$ according to capacity type (RT or $O T$ ):

$$
\begin{aligned}
& S U R_{i p R}=U F_{p}-\sum_{k=i}^{N} X_{i p k} \\
& S U R_{i p o}=V F_{p}-\sum_{k=i}^{N} Y_{i p k}
\end{aligned}
$$

Improvement Phase

Step 3. For period $i=N$ down to $l$ do:

3.1 Redistribute $\left\{Y_{i p k}, Y_{i p(k+1), \ldots,}, Y_{i p N}\right\}$ to any available surplus capacity in previous periods ( $R T$ first, then $O T$; start with the most recent past period and work backward in time) provided both of the following conditions are met: (i) there is sufficient surplus capacity in those previous periods to completely eliminate the setup for the overtime shift in period $i$ and efficient level $p$; (ii) the additional inventory cost caused by the redistribution is less than the cost of this setup (i.e. payroll cost of the overtime shift).

3.2 Update surplus capacity in all periods and efficiency levels according to capacity type ( $R T$ or $O T)$ :

$$
\begin{array}{ll}
S U R_{i j R}=U F_{j}-\sum_{k=i}^{N} X_{i j k} & (i=1,2, \ldots N ; j=1,2, \ldots M) \\
S U R_{i j o}=V F_{j}-\sum_{k=i}^{N} Y_{i j k} & (i=1,2, \ldots N ; j=1,2, \ldots M)
\end{array}
$$

The application of the heuristic is illustrated using two $6 \times 2$ (six periods, two efficiency levels) numerical examples below.

Numerical Example I

Data:

$N=6 ; M=2$

$D=\{280,320,300,350,340,280\}$

$F=\{30,40\} ; G=\{10,14\}$

$R=\$ 20 ; O=\$ 30$

$U=8 ; V=2$

$H=\$ 2$

$B$ : Backlogging is not permitted (we assign a prohibitively high cost in the model to enforce this restriction) 
The fixed costs are:

$$
\begin{aligned}
& R U G_{1}=\$ 1600 \\
& O V G_{1}=\$ 600 \\
& R U G_{2}=\$ 2240 \\
& O V G_{2}=\$ 840
\end{aligned}
$$

And capacities:

\begin{tabular}{|c|c|c|c|c|c|c|c|c|c|c|}
\hline Period & $\begin{array}{c}\text { Efficiency } \\
\text { Level }\end{array}$ & $\begin{array}{c}\text { Capacity } \\
\text { Type }\end{array}$ & $\begin{array}{c}\text { Fixed } \\
\text { Cost }\end{array}$ & $\begin{array}{c}\text { Period } \\
1\end{array}$ & $\begin{array}{l}\text { Period } \\
2\end{array}$ & $\begin{array}{c}\text { Period } \\
3\end{array}$ & $\begin{array}{c}\text { Period } \\
4\end{array}$ & $\begin{array}{c}\text { Period } \\
5\end{array}$ & $\begin{array}{c}\text { Period } \\
6\end{array}$ & Capacity \\
\hline \multirow{4}{*}{1} & \multirow{2}{*}{ Level 1} & RT & 1600 & 0 & 2 & 4 & 6 & 8 & 10 & 240 \\
\hline & & OT & 600 & 0 & 2 & 4 & 6 & 8 & 10 & 60 \\
\hline & \multirow{2}{*}{ Level 2} & RT & 2240 & 0 & 2 & 4 & 6 & 8 & 10 & 320 \\
\hline & & OT & 840 & 0 & 2 & 4 & 6 & 8 & 10 & 80 \\
\hline \multirow{4}{*}{2} & \multirow{2}{*}{ Level 1} & RT & 1600 & & 0 & 2 & 4 & 6 & 8 & 240 \\
\hline & & OT & 600 & & 0 & 2 & 4 & 6 & 8 & 60 \\
\hline & \multirow{2}{*}{ Level 2} & RT & 2240 & & 0 & 2 & 4 & 6 & 8 & 320 \\
\hline & & OT & 840 & & 0 & 2 & 4 & 6 & 8 & 80 \\
\hline \multirow{4}{*}{3} & \multirow{2}{*}{ Level 1} & RT & 1600 & & & 0 & 2 & 4 & 6 & 240 \\
\hline & & OT & 600 & & & 0 & 2 & 4 & 6 & 60 \\
\hline & \multirow{2}{*}{ Level 2} & RT & 2240 & & & 0 & 2 & 4 & 6 & 320 \\
\hline & & OT & 840 & & & 0 & 2 & 4 & 6 & 80 \\
\hline \multirow{4}{*}{4} & \multirow{2}{*}{ Level 1} & RT & 1600 & & & & 0 & 2 & 4 & 240 \\
\hline & & OT & 600 & & & & 0 & 2 & 4 & 60 \\
\hline & \multirow{2}{*}{ Level 2} & RT & 2240 & & & & 0 & 2 & 4 & 320 \\
\hline & & OT & 840 & & & & 0 & 2 & 4 & 80 \\
\hline \multirow{4}{*}{5} & \multirow{2}{*}{ Level 1} & RT & 1600 & & & & & 0 & 2 & 240 \\
\hline & & OT & 600 & & & & & 0 & 2 & 60 \\
\hline & \multirow{2}{*}{ Level 2} & RT & 2240 & & & & & 0 & 2 & 320 \\
\hline & & OT & 840 & & & & & 0 & 2 & 80 \\
\hline \multirow{4}{*}{6} & \multirow{2}{*}{ Level 1} & RT & 1600 & & & & & & 0 & 240 \\
\hline & & OT & 600 & & & & & & 0 & 60 \\
\hline & \multirow{2}{*}{ Level 2} & RT & 2240 & & & & & & 0 & 320 \\
\hline & & OT & 840 & & & & & & 0 & 80 \\
\hline Demand & & & & 280 & 320 & 300 & 350 & 340 & 280 & \\
\hline
\end{tabular}

$$
\begin{aligned}
& U F_{1}=240 \\
& V F_{1}=60 \\
& U F_{2}=320 \\
& V F_{2}=80
\end{aligned}
$$

The completed tableau is depicted in Table 7.

Table 7. Tableau for $6 \times 2$ Numerical Example I 
An initial feasible solution, generated by the construction phase, is as follows:

Table 8. Initial Solution for Numerical Example I

\begin{tabular}{|c|c|c|c|c|c|c|c|c|c|c|}
\hline Period & $\begin{array}{c}\text { Efficiency } \\
\text { Level }\end{array}$ & $\begin{array}{c}\text { Capacity } \\
\text { Type }\end{array}$ & $\begin{array}{c}\text { Fixed } \\
\text { Cost } \\
\end{array}$ & $\begin{array}{c}\text { Period } \\
1 \\
\end{array}$ & $\begin{array}{c}\text { Period } \\
2 \\
\end{array}$ & $\begin{array}{c}\text { Period } \\
3 \\
\end{array}$ & $\begin{array}{c}\text { Period } \\
4 \\
\end{array}$ & $\begin{array}{c}\text { Period } \\
5 \\
\end{array}$ & $\begin{array}{c}\text { Period } \\
6 \\
\end{array}$ & Capacity \\
\hline \multirow{2}{*}{1} & Level 1 & $\begin{array}{l}\text { RT } \\
\text { OT }\end{array}$ & $\begin{array}{c}1600 \\
600\end{array}$ & $\begin{array}{c}240 \\
40\end{array}$ & & & & & & $\begin{array}{c}240 \\
60\end{array}$ \\
\hline & Level 2 & $\begin{array}{l}\text { RT } \\
\text { OT }\end{array}$ & $\begin{array}{c}2240 \\
840\end{array}$ & & & & & & & $\begin{array}{c}320 \\
80\end{array}$ \\
\hline \multirow{2}{*}{2} & Level 1 & $\begin{array}{l}\text { RT } \\
\text { OT }\end{array}$ & $\begin{array}{c}1600 \\
600\end{array}$ & & & & & & & $\begin{array}{c}240 \\
60\end{array}$ \\
\hline & Level 2 & $\begin{array}{l}\text { RT } \\
\text { OT }\end{array}$ & $\begin{array}{c}2240 \\
840 \\
\end{array}$ & & 320 & & & & & $\begin{array}{c}320 \\
80 \\
\end{array}$ \\
\hline \multirow{2}{*}{3} & Level 1 & $\begin{array}{l}\text { RT } \\
\text { OT }\end{array}$ & $\begin{array}{c}1600 \\
600\end{array}$ & & & $\begin{array}{c}240 \\
60\end{array}$ & & & & $\begin{array}{c}240 \\
60\end{array}$ \\
\hline & Level 2 & $\begin{array}{l}\text { RT } \\
\text { OT }\end{array}$ & $\begin{array}{c}2240 \\
840\end{array}$ & & & & & & & $\begin{array}{c}320 \\
80\end{array}$ \\
\hline \multirow[b]{2}{*}{4} & Level 1 & $\begin{array}{l}\text { RT } \\
\text { OT }\end{array}$ & $\begin{array}{c}1600 \\
600\end{array}$ & & & & & & & $\begin{array}{c}240 \\
60\end{array}$ \\
\hline & Level 2 & $\begin{array}{l}\text { RT } \\
\text { OT }\end{array}$ & $\begin{array}{c}2240 \\
840\end{array}$ & & & & $\begin{array}{c}320 \\
30 \\
\end{array}$ & & & $\begin{array}{c}320 \\
80 \\
\end{array}$ \\
\hline \multirow{2}{*}{5} & Level 1 & $\begin{array}{l}\text { RT } \\
\text { OT }\end{array}$ & $\begin{array}{c}1600 \\
600 \\
\end{array}$ & & & & & & & $\begin{array}{c}240 \\
60\end{array}$ \\
\hline & Level 2 & $\begin{array}{l}\text { RT } \\
\text { OT }\end{array}$ & $\begin{array}{c}2240 \\
840\end{array}$ & & & & & $\begin{array}{c}320 \\
20\end{array}$ & & $\begin{array}{c}320 \\
80\end{array}$ \\
\hline \multirow{2}{*}{6} & Level 1 & $\begin{array}{l}\text { RT } \\
\text { OT } \\
\end{array}$ & $\begin{array}{c}1600 \\
600 \\
\end{array}$ & & & & & & $\begin{array}{c}240 \\
40\end{array}$ & $\begin{array}{c}240 \\
60 \\
\end{array}$ \\
\hline & Level 2 & $\begin{array}{l}\text { RT } \\
\text { OT }\end{array}$ & $\begin{array}{c}2240 \\
840\end{array}$ & & & & & & & $\begin{array}{c}320 \\
80\end{array}$ \\
\hline Demand & & & & 280 & 320 & 300 & 350 & 340 & 280 & \\
\hline
\end{tabular}

The cost of this solution is as follows:

Production regular-time: $\$ 11,520$

Production overtime: $\$ 3,480$

Inventory holding: $\$ 0$

Total cost: $\$ 15,000$

An improved solution after applying the first swap (of Period 6's Level 1 OT production quantity of 40 units) is shown next. 
Table 9. Improved Solution for Numerical Example I (after one swap)

\begin{tabular}{|c|c|c|c|c|c|c|c|c|c|c|}
\hline Period & $\begin{array}{c}\text { Efficiency } \\
\text { Level }\end{array}$ & $\begin{array}{c}\text { Capacity } \\
\text { Type }\end{array}$ & $\begin{array}{c}\text { Fixed } \\
\text { Cost }\end{array}$ & $\begin{array}{c}\text { Period } \\
1 \\
\end{array}$ & $\begin{array}{c}\text { Period } \\
2 \\
\end{array}$ & $\begin{array}{c}\text { Period } \\
3 \\
\end{array}$ & $\begin{array}{c}\text { Period } \\
4 \\
\end{array}$ & $\begin{array}{c}\text { Period } \\
5 \\
\end{array}$ & $\begin{array}{c}\text { Period } \\
6\end{array}$ & Capacity \\
\hline \multirow[b]{2}{*}{1} & Level 1 & $\begin{array}{l}\text { RT } \\
\text { OT }\end{array}$ & $\begin{array}{c}1600 \\
600\end{array}$ & $\begin{array}{c}240 \\
40\end{array}$ & & & & & & $\begin{array}{c}240 \\
60\end{array}$ \\
\hline & Level 2 & $\begin{array}{l}\text { RT } \\
\text { OT }\end{array}$ & $\begin{array}{c}2240 \\
840\end{array}$ & & & & & & & $\begin{array}{c}320 \\
80 \\
\end{array}$ \\
\hline \multirow{2}{*}{2} & Level 1 & $\begin{array}{l}\text { RT } \\
\text { OT } \\
\end{array}$ & $\begin{array}{c}1600 \\
600 \\
\end{array}$ & & & & & & & $\begin{array}{c}240 \\
60\end{array}$ \\
\hline & Level 2 & $\begin{array}{l}\text { RT } \\
\text { OT }\end{array}$ & $\begin{array}{c}2240 \\
840\end{array}$ & & 320 & & & & & $\begin{array}{c}320 \\
80\end{array}$ \\
\hline \multirow{2}{*}{3} & Level 1 & $\begin{array}{l}\text { RT } \\
\text { OT }\end{array}$ & $\begin{array}{c}1600 \\
600\end{array}$ & & & $\begin{array}{c}240 \\
60\end{array}$ & & & & $\begin{array}{c}240 \\
60\end{array}$ \\
\hline & Level 2 & $\begin{array}{l}\text { RT } \\
\text { OT }\end{array}$ & $\begin{array}{c}2240 \\
840 \\
\end{array}$ & & & & & & & $\begin{array}{c}320 \\
80\end{array}$ \\
\hline \multirow{2}{*}{4} & Level 1 & $\begin{array}{l}\text { RT } \\
\text { OT }\end{array}$ & $\begin{array}{c}1600 \\
600\end{array}$ & & & & & & & $\begin{array}{c}240 \\
60\end{array}$ \\
\hline & Level 2 & $\begin{array}{l}\text { RT } \\
\text { OT }\end{array}$ & $\begin{array}{c}2240 \\
840\end{array}$ & & & & $\begin{array}{c}320 \\
30\end{array}$ & & & $\begin{array}{c}320 \\
80\end{array}$ \\
\hline \multirow[b]{2}{*}{5} & Level 1 & $\begin{array}{l}\text { RT } \\
\text { OT }\end{array}$ & $\begin{array}{c}1600 \\
600\end{array}$ & & & & & & & $\begin{array}{c}240 \\
60\end{array}$ \\
\hline & Level 2 & $\begin{array}{l}\text { RT } \\
\text { OT }\end{array}$ & $\begin{array}{c}2240 \\
840\end{array}$ & & & & & $\begin{array}{c}320 \\
20\end{array}$ & 40 & $\begin{array}{c}320 \\
80\end{array}$ \\
\hline \multirow{2}{*}{6} & Level 1 & $\begin{array}{l}\text { RT } \\
\text { OT }\end{array}$ & $\begin{array}{c}1600 \\
600\end{array}$ & & & & & & 240 & $\begin{array}{c}240 \\
60\end{array}$ \\
\hline & Level 2 & $\begin{array}{l}\text { RT } \\
\text { OT }\end{array}$ & $\begin{array}{c}2240 \\
840\end{array}$ & & & & & & & $\begin{array}{c}320 \\
80\end{array}$ \\
\hline Demand & & & & 280 & 320 & 300 & 350 & 340 & 280 & \\
\hline
\end{tabular}

The cost of this solution is as follows:

Production regular-time: $\$ 11,520$

Production overtime: $\$ 2,880$

Inventory holding: $\$ 80$

Total cost: $\$ 14,480$

Thus the overtime shift in Period 6 with a setup cost of $\$ 600$ was eliminated for an additional inventory cost of only $\$ 80$, yielding a net saving of $\$ 520$. A further improved solution after the second and final swap (of Period 5's Level 2 OT production quantities of $\mathbf{2 0}$ and $\mathbf{4 0}$ units) is shown next. 
Table 10. Improved Solution for Numerical Example I (after second and final swap)

\begin{tabular}{|c|c|c|c|c|c|c|c|c|c|c|}
\hline Period & $\begin{array}{c}\text { Efficiency } \\
\text { Level }\end{array}$ & $\begin{array}{c}\text { Capacity } \\
\text { Type }\end{array}$ & $\begin{array}{c}\text { Fixed } \\
\text { Cost }\end{array}$ & $\begin{array}{c}\text { Period } \\
1\end{array}$ & $\begin{array}{c}\text { Period } \\
2\end{array}$ & $\begin{array}{c}\text { Period } \\
3\end{array}$ & $\begin{array}{c}\text { Period } \\
4\end{array}$ & $\begin{array}{c}\text { Period } \\
5\end{array}$ & $\begin{array}{c}\text { Period } \\
6\end{array}$ & Capacity \\
\hline \multirow{2}{*}{1} & Level 1 & $\begin{array}{l}\text { RT } \\
\text { OT }\end{array}$ & $\begin{array}{c}1600 \\
600\end{array}$ & $\begin{array}{c}240 \\
40\end{array}$ & & & & & 10 & $\begin{array}{c}240 \\
60\end{array}$ \\
\hline & Level 2 & $\begin{array}{l}\text { RT } \\
\text { OT }\end{array}$ & $\begin{array}{c}2240 \\
840\end{array}$ & & & & & & & $\begin{array}{c}320 \\
80\end{array}$ \\
\hline \multirow{2}{*}{2} & Level 1 & $\begin{array}{l}\text { RT } \\
\text { OT }\end{array}$ & $\begin{array}{c}1600 \\
600\end{array}$ & & & & & & & $\begin{array}{c}240 \\
60\end{array}$ \\
\hline & Level 2 & $\begin{array}{l}\text { RT } \\
\text { OT }\end{array}$ & $\begin{array}{c}2240 \\
840\end{array}$ & & 320 & & & & & $\begin{array}{c}320 \\
80\end{array}$ \\
\hline \multirow{2}{*}{3} & Level 1 & $\begin{array}{l}\text { RT } \\
\text { OT }\end{array}$ & $\begin{array}{c}1600 \\
600\end{array}$ & & & $\begin{array}{c}240 \\
60 \\
\end{array}$ & & & & $\begin{array}{c}240 \\
60 \\
\end{array}$ \\
\hline & Level 2 & $\begin{array}{l}\text { RT } \\
\text { OT }\end{array}$ & $\begin{array}{c}2240 \\
840\end{array}$ & & & & & & & $\begin{array}{c}320 \\
80\end{array}$ \\
\hline \multirow[b]{2}{*}{4} & Level 1 & $\begin{array}{l}\text { RT } \\
\text { OT }\end{array}$ & $\begin{array}{c}1600 \\
600\end{array}$ & & & & & & & $\begin{array}{c}240 \\
60\end{array}$ \\
\hline & Level 2 & $\begin{array}{l}\text { RT } \\
\text { OT }\end{array}$ & $\begin{array}{c}2240 \\
840 \\
\end{array}$ & & & & $\begin{array}{c}320 \\
30 \\
\end{array}$ & 20 & 30 & $\begin{array}{c}320 \\
80 \\
\end{array}$ \\
\hline \multirow{2}{*}{5} & Level 1 & $\begin{array}{l}\text { RT } \\
\text { OT }\end{array}$ & $\begin{array}{c}1600 \\
600\end{array}$ & & & & & & & $\begin{array}{c}240 \\
60\end{array}$ \\
\hline & Level 2 & $\begin{array}{l}\text { RT } \\
\text { OT }\end{array}$ & $\begin{array}{c}2240 \\
840 \\
\end{array}$ & & & & & 320 & & $\begin{array}{c}320 \\
80 \\
\end{array}$ \\
\hline \multirow{2}{*}{6} & Level 1 & $\begin{array}{l}\text { RT } \\
\text { OT }\end{array}$ & $\begin{array}{c}1600 \\
600\end{array}$ & & & & & & 240 & $\begin{array}{c}240 \\
60\end{array}$ \\
\hline & Level 2 & $\begin{array}{l}\text { RT } \\
\text { OT }\end{array}$ & $\begin{array}{c}2240 \\
840\end{array}$ & & & & & & & $\begin{array}{c}320 \\
80\end{array}$ \\
\hline Demand & & & & 280 & 320 & 300 & 350 & 340 & 280 & \\
\hline
\end{tabular}

The cost of this solution is as follows:

Production regular-time: $\$ 11,520$

Production overtime: $\$ 2,040$

Inventory holding: $\$ 260$

Total cost: $\$ \mathbf{\$ 1 3 , 8 2 0}$

Thus the overtime shift in Period 5 with a setup cost of $\$ 840$ was eliminated for an additional inventory cost of only $\$ 180$, yielding a net saving of $\$ 660$. The heuristic terminates at this point since there is not enough surplus capacity available in prior periods to warrant canceling any overtime shifts.

The optimal objective value for this example (found using Excel Solver) is $\$ 13,660$. Therefore the initial heuristic solution reflects a $9.81 \%$ optimality gap which is reduced to only $1.17 \%$ after applying the two swaps.

\section{Numerical Example II}

Only the demands are changed from the previous example: $D=\{280,320,300,350,340, \mathbf{5 0 0}\}$. All other data remain the same.

The cost of the initial feasible solution generated by the construction phase:

Production regular-time: $\$ 12,160$

Production overtime: $\$ 3,720$

Inventory holding: $\$ 280$

Total cost: $\$ 16,160$ 
There is no scope for swaps at this point since there is insufficient surplus capacity available in prior periods to absorb a later shift's entire production quantity (note: only 30 units of excess capacity is available over the planning horizon). Therefore no further overtime shifts can be canceled, and the heuristic terminates at the end of the construction phase. The optimal objective value for this example also happens to be $\$ 16,160$. Therefore the initial heuristic solution reflects a $0 \%$ optimality gap.

\section{CONCLUSION}

We have extended the traditional production planning problem to incorporate line balance. The model and heuristic presented here explicitly include the efficiency of production lines in making production and short-term capacity decisions. Although our mathematical formulation considered only regular-time and overtime capacity types, it can easily be expanded to include other types of capacity such as subcontracting. This model would be useful to managers in understanding efficiency and capacity implications on the production planning process.

\section{AUTHOR INFORMATION}

Kingsley Gnanendran is Professor of Operations Management, and Director of the Online MBA program in the Kania School of Management at The University of Scranton. His current teaching and research interests are in the area of supply chain management. His work has been published in the European Journal of Operational Research, Decision Support Systems, International Journal of Production Economics, and several other journals. He can be reached at: $\underline{\text { skingsley.gnanendran@scranton.edu. }}$

Manohar Madan is a Professor in the Information Technology and Supply Chain Management Department in the College of Business and Economics at the University of Wisconsin-Whitewater. His teaching and research interests are in the area of Operations and Supply Chain Management. Manohar's research has been published in many professional journals such as the Journal of Operations Management, IIE Transactions, OMEGA, International Journal of Operations and Production Management, International Journal of Production Research and the Journal of Operational Research Society. He can be reached at: madanm@uww.edu.

\section{REFERENCES}

Bowman, E.H. (1963). Consistency and optimality in managerial decision making. Management Science, 9(2), 310321.

Brahimi, N., Dauzere-Peres, S., and Najid, N.M. (2006). Capacitated multi-item lot-sizing problems with time windows. Operations Research, 54(5), 951-967.

Cheng, C.H., Madan, M.S., Gunasekaran, A., and Yip, K.Y. (2010). An algorithm using Lagrangean relaxation and decomposition for solving a capacitated lot sizing problem. International Journal of Mathematics in Operational Research, 2(2), 205-232.

Diaby, M., Bahl, H.C., Karwan, M.H., and Zionts, S. (1992). A Lagrangean relaxation approach for very-large-scale capacitated lot-sizing. Management Science, 38(9), 1329-1340.

Dixon, P., and Silver, E. (1981). A heuristic solution procedure for the multi-item, single-level, limited capacity lotsizing problem. Journal of Operations Management, 2(1), 23-39.

Dogramaci, A., Panayiotopoulos, J.C., and Adam, N.R. (1981). The dynamic lot-sizing problem for multiple-item, single level, limited capacity, lot-sizing problem. Journal of Operations Management, 2(1), 23-39.

Eisenhut, P.S. (1975). A dynamic lot sizing algorithm with capacity constraints. AIIE Transactions, 7(2), 170-176.

Garg, S., Vrat, P., and Kanda, A. (2002). Trade-offs between multiskilling and inventory in assembly line operations under demand variability. International Journal of Operations \& Production Management, 22(5/6), 565583.

Gilbert, K., and Madan, M. (1991). A heuristic for a class of production planning and scheduling problems. IIE Transactions, 23(2), 282- 289.

Jans, R., and Degraeve, Z. (2007). Meta-heuristics for dynamic lot sizing: a review and comparison of solution approaches. European Journal of Operational Research, 177(3), 1855-1875.

Krajewski, L.J., Ritzman, L.P., and Malhotra, M.K. (2013). Operations Management: Processes and Supply Chains, Tenth Edition. Boston, MA: Pearson/Prentice-Hall. 
Lambrecht, M.R. and Vanderveken, H. (1979). Heuristic procedure for the single operation multi-item loading problem. AIIE Transactions, 11(4), 19-326.

Madan, M., and Gilbert, K. (1992). An exact solution algorithm for a class of production planning and scheduling problems. Journal of the Operational Research Society, 43(10), 961-970.

Maes, J. and Van Wassenhove, L. (1988). Multi-item single-level dynamic lot-sizing heuristics: a general review. Journal of the Operational Research Society, 38(11), 991-1004.

Meredith, J.R., and Shafer, S. (2010). Operations Management for MBAs, Fourth Edition. Hoboken, NJ: John Wiley \& Sons.

Millar, H.H., and Yang, M. (1993). An application of Lagrangean decomposition to the capacitated multi-item lot sizing problem. Computers and Operations Research, 20(4), 409-420.

Millar, H.H., and Yang, M. (1994). Lagrangean heuristics for the capacitated multi-item lot-sizing problem with backordering. International Journal of Production Economics, 34, 1-15.

Scholl, A., and Becker, C. (2006). State-of-the-art exact and heuristic solution procedures for simple assembly line balancing. European Journal of Operational Research, 168, 666-693. 